\title{
The Representation of Theatricality in Philo's Embassy to Gaius
}

\author{
Ellen Muehlberger \\ Department of Religious Studies Indiana University Bloomington, IN 47405, USA \\ emuehlbe@indiana.edu
}

\begin{abstract}
In this paper I argue that Philo's Embassy to Gaius makes use of the literary paradigm of theatricality, a strategy of representation marked by the portrayal of multiple and competing discourses amongst those in unequal relations of power, as well as an emphasis on the arts of acting and discernment. The Embassy marks an appearance of the theatrical paradigm which is earlier than its use by Tacitus, whose portrayal of Nero in the Annals Shadi Bartsch has seen as the harbinger of this theme in Roman historiography.
\end{abstract}

\section{Keywords}

Philo of Alexandria, Embassy to Gaius, theatricality, emperor-subject relations, Tacitus

In the last century and a half of the Second Temple period, from Pompey's conquest of Jerusalem in 63 B.C.E. until the destruction of the Temple by Titus in 70 C.E., the Jews - inasmuch as the religious groups scattered throughout the Mediterranean can be considered a group-were under Roman rule. Our two main Jewish sources for this period, Philo and Josephus, are certainly historians and provide us with invaluable information about Jewish life, especially about the Jewish Revolt of 66-70 C.E. Like any other Roman subject, though, Philo and Josephus also engage in negotiations with the power of the emperor, whether immediate or mediated. One scholar of the Roman world has suggested that the impulse to address the emperor in subject literature is more than just flattery, actually being a potential influence on those in power. In a discussion of Tacitus and the place of historiography in resistance against the empire, Barbara Levick remarked: 
If Trajan or Hadrian were among the readers of Tacitus and were aware of the rest of his audience (however far that extended beyond the social and intellectual elite) that would set up a triangular relationship between the author, the emperor and the rest of his audience, that might have a practical effect on the emperor's perception of himself, his office, and his future reputation, and so on his behaviour. ${ }^{1}$

Thus Levick suggests that while Tacitus may not have addressed the emperor directly, it is feasible that Trajan or Hadrian could be influenced by Tacitus's historical works. It is a short leap from that statement to the idea that Tacitus, considering the effect his work might have on those in power, could write a treatise with the emperor as an imagined audience without ever making his intent explicit. It is not surprising, then, given this line of thought, to find the person of the emperor as an implicit addressee in all kinds of works by Roman subjects, Philo and Josephus included.

The classical historian Shadi Bartsch has argued that the tendency of Roman writers to give special consideration to the emperor as a potential audience of their works develops into an entirely new sensibility under Nero (54-68 C.E.). ${ }^{2}$ Borrowing the concept of "theatricality" from James C. Scott's Domination and the Arts of Resistance and other scholars of cultural studies, ${ }^{3}$ Bartsch argues that the start of Nero's famous acting career

1) This essay was first presented at a graduate-faculty workshop sponsored by the Borns Jewish Studies Program at Indiana University. I am particularly thankful to Steven Weitzman, in whose seminar on Hellenistic Judaism I began this project; his encouragement, expertise, and general good cheer certainly helped it along. Chris Frilingos, Diane Fruchtman, and Gina Brandolino made helpful suggestions at different stages of its development, and I am grateful as well for the comments of the two anonymous reviewers for JSJ. Any infelicities that may be revealed are truly my own.

Remark found in Opposition et résistances à l'empire d'Auguste à Trajan: neuf exposés suivis de discussions, ed. Kurt A. Raaflaub (Geneva: Fondation Hardt, 1987), 101.

2) Shadi Bartsch, Actors in the Audience: Theatricality and Doublespeak from Nero to Hadrian (Cambridge, MA: Harvard University Press, 1994).

3) James C. Scott, Domination and the Arts of Resistance: Hidden Transcripts (New Haven, CT: Yale University Press, 1990); see also Erving Goffman, "The Nature of Deference and Demeanor," in Interaction Ritual: Essays on Face-to-Face Behavior (Garden City, NY: Doubleday, 1967), 47-95, and Elizabeth Burns, Theatricality: A Study of Convention in the Theatre and in Social Life (New York: Harper \& Row, 1972), cited by Bartsch, Actors in the Audience, 12 n. 23. 
precipitates the depiction of theatricality in Roman historians. While Roman writers had always kept an eye on the potential imperial readers of their work, Nero's ascent to the stage reversed the usual expectations of actor and audience and created new notions of how subjects respond to imperial will. In particular, Bartsch observes the following:

Abandoning his position in the audience, Nero takes to the stage himself, there to recite his poetry, sing to the lyre, and interpret tragic roles, so that the mutual gaze of emperor and spectators now transpires across the dividing line of the seats and the stage, across the boundary that separates the real from the representational. And while the most prominent member of the audience has literally moved to the stage, the rest of the audience find themselves obliged, not to suppress their noisy petitions - when Nero performs, mentions of these are largely absent-but rather to display their response to the artistic performance of their own emperor. ${ }^{4}$

That is, even as he was performing, Nero and his servants would watch the audience members, judging their reaction to the performance and formulating ideas from their observations about the audience's loyalty to the emperor. Thus, subjects were forced to adopt an approving disposition, even if Nero's ability left much to be desired; hence Bartsch's title, Actors in the Audience. In this way, theatricality comes to define the relationship between Nero and his subjects while he is on stage, but it also characterizes relations outside the theater. Particularly important is the way that this theatrical paradigm demands that subjects both attempt to discern the will of the emperor and, at the same time, to act as if they agree with that will. A worldview dominated by theatricality

makes actors out of human beings placed in situations in which they feel themselves watched, in which their performance is subject to the evaluation of a superior who must be watched in turn to gauge his reactions; and in those contexts in which there exists a well-defined, self-conscious audience (as with Nero's stage performances - or modern meta-theater), it entails a reversal of the normal one-way direction of the spectators' gaze, so that they know themselves watched by the object of their view and respond accordingly even as the categories of spectacle and spectator lose all stability. ${ }^{5}$

4) Bartsch, Actors in the Audience, 2-3.

5) Bartsch, Actors in the Audience, 10-11. 
It is with such a rubric, Bartsch writes, that Tacitus chooses to represent the precarious position of subjects under Nero, particularly in the Annals. ${ }^{6}$ Tacitus's portrayal of subjects as having two dispositions - that which guilelessly supports Nero and approves of his actions and that which disapproves of his actions, but in secret-and his emphasis on the necessity of acting incumbent upon subjects are the markers of the theatrical paradigm that Bartsch sees in Tacitus's representation of Nero's reign.

It is clear, however, that the literary representation of theatricality in the context of Roman emperor-subject relations thus defined does not, as Bartsch claims, begin with the first writings about Nero's appearance on stage. Philo of Alexandria's Embassy to Gaius ${ }^{7}$ was written as a reflection on the troubles of Gaius Caligula's reign and was most likely intended for a reading audience that included Claudius, Gaius's successor. ${ }^{8}$ The Embassy, appearing at least 10 years before Nero's performative career, represents the relationships between Gaius and his subjects in the terms of the deception and dissimulation that Bartsch finds in Tacitus.

This essay will explore Philo's representation in two parts. First, it will consider a pair of scenes from the Embassy: the interaction between Gaius and Petronius, his Syrian viceroy; and the interaction between Gaius and Agrippa, the Jew appointed "king" over Palestine. Here appears the sort of theatricality that Bartsch considers the hallmark of Tacitus's writing about Neronian subjects, yet in an earlier context. One difference, I will argue, is that while Tacitus relies on descriptive accounts of subjects' plurality of mind, Philo creates internal monologues to portray the varied modes of emotion and subjection. ${ }^{9}$ Elsewhere in the Embassy, rather than represent

๑) Bartsch, Actors in the Audience, 1-35, esp. 31.

7) Philo, Embassy to Gaius (trans. F. H. Colson; LCL; Cambridge: Harvard University Press, 1962). I do not depart in this essay from the translation of Colson.

8) Erwin Goodenough, the early yet astute epitomator of Philo's political thought, writes that the Embassy "has the most elaborate formulation of what was the function of a proper ruler, and what effect he should have upon his subjects and realm," noting that "such formulation Philo himself never expresses in his own name, but always puts into the mouth of another," and suggesting that, given the praise heaped on Claudius in Embassy, he is its most likely intended recipient. See The Politics of Philo Judaeus: Practice and Theory (New Haven, CT: Yale University Press, 1938), 19.

9) Bartsch suggests that Tacitus allows his readers "admission to the thoughts and fears of Nero's victims as they hastily slip on their masks before the emperor" (Actors in the Audience, 22), and indeed, his writing about the affairs of Britannicus (Ann. 13.15.2-3; cited by Bartsch, Actors in the Audience, 14), Octavia, his sister (Ann. 13.16.3-4; cited by Bartsch, Actors in the Audience, 15), Julius Montanus (Ann. 13.25.2; cited by Bartsch, Actors in the 
two competing transcripts - one that supports Gaius, one that does notwithin a single subject, Philo places the opposing transcripts in two different characters. In the second part of this essay, I examine how Philo, by setting his own narrative voice against that of "the crowd," is able to utilize the tools of theatricality, but does so in a way that maintains a certain political conservatism. The overall effect of these considerations will be to demonstrate that Philo's representation of the theatricality of relations between the Roman emperor and his subjects is indeed earlier, but also more complex and more flexible, than its use in the work of Tacticus, which Bartsch presents as the harbinger of this paradigm in Roman writing.

\section{Gaius and His Subjects: Theatricality in the Embassy}

In 38 C.E., Greeks in Alexandria rioted against Jews, pushing them out of their homes, destroying their businesses, and desecrating their synagogues with statues representing the emperor Gaius. What is worse, while Philo and the rest of the emergency envoy sent to the emperor from Alexandria's Jewish community were waiting to be granted an audience with Gaius to address these wrongs, word came that Gaius intended to introduce a statue of himself as Zeus, not into one of the local synagogues, but into the very temple at Jerusalem. These are the central events described in Philo's Embassy to Gaius, a text in which Philo skillfully modulates between presenting himself as a character in the narrative-one of the leaders of the envoy - and adopting the narrative voice of the author. In order to discuss Philo's representation of theatricality between emperor and subject, let us consider two scenes from this work.

The first depicts an exchange of letters between Gaius and his Syrian viceroy Petronius (Embassy 243-60). The scene, albeit concise, is not a simple case, neither portraying assent to imperial will, nor showcasing the adulation of an imperial performance. Rather, Philo shows us that even as Gaius orders Petronius to make preparations to install this statue of himself as Zeus in the temple, Petronius acts to thwart the emperor's will, all while smoothing over the appearance of this disobedience.

Audience, 19), and lastly, Agrippina (Ann. 14.6.1-8.4; cited by Bartsch, Actors in the Audience, 21) does describe the assumptions and feelings of these characters and their misguided attempts to evade Nero's disapproval. However, my point here is that Philo uses an entirely different strategy: the reporting of internal reasoning, presented in the hypothetical first person. 
Philo does so using a narrative perspective that allows us access to Petronius's thoughts, a move that reveals to the reader the double nature of this character's intent. Petronius, having received a desperate plea from local Jewish elders not to proceed with the installation, mercifully decides to stall Gaius with "a letter in which, without accusing the Jews or giving a candid account of their prayers and entreaties, he would charge the delay in the installation partly to the work requiring a definite allowance of time for the construction, partly to the season, which gave strong grounds for delay" (248). Thus Petronius, having compassion on the local Jewish population, begins to sabotage Gaius's plans. He is cognizant of the peril of opposing imperial will, however, and couches his refusal in unassailable terms: he is hampered by the dictates of nature and the amount of work required for the installation, things that cannot be helped (248-53). Philo goes on to show us that Petronius is convinced that his excuses will fool Gaius, in that he thinks to himself that Gaius "will probably not merely refrain from anger but approve our forethought, recognizing that the postponement which we have made is not due to favouritism to the Jews but in order to insure the carrying of the harvest" (253). So, in Philo's representation, Petronius knows enough to hide his obstinacy underneath a veneer of caution and care, hoping that the appearance of a dutiful subject will overshadow the fact of his noncompliance.

As Gaius receives the letter, however, Philo reveals that no one has been fooled. Immediately Gaius knows that Petronius is dissimulating: "While he was still reading [the letter he] was fuming and was filled with wrath at each point" (254). Philo then allows us to hear Gaius's thoughts as he sarcastically addresses the absent Petronius, "Go on, plead the harvest as your pretext; the harvest for which no pretext will avail will soon be visited on your own head. Yes, lay the blame on the ingathering of the fruits and the preparations needed for our journey" (257). Gaius goes on, questioning the shallow pretense of Petronius's delaying tactic: "Why, even if complete barrenness reigned in Judaea were not the neighbouring countries so many and so prosperous capable of providing the necessaries and compensating the deficiency in one?" (257) Petronius certainly attempts to hide the true motives for his delay in installing the statue, but Gaius is able to understand the real problem. He warns the distant viceroy ominously: "Up to this time you seem to have no knowledge of Gaius even by report; you will soon know him by actual experience" (255).

Petronius, the reader soon discovers, is not the only character capable of hiding his motives. At this point, Gaius engages in a little dissimulation of 
his own, dictating a letter in response to Petronius in which "he seemingly praised him for his forethought and his careful exploration of future requirements." As Philo explains, "his language and letters were ingratiating, and though furiously angry he disguised his rancour waiting for an opportunity" (260). While it sounds as though Gaius is acting strategically, Philo is quick to point out, rather, that Gaius does not reveal his discovery because he is afraid of the power that Petronius holds, because "he greatly feared the holders of governorships, [for] he saw that they had resources ready for an uprising, particularly those who had large provinces and commanded large armies of the size of those in Syria on the Euphrates" (259).

Here we have evidently departed from a clean and simple model of imperial power and subject appeasement. In his Domination and the Arts of Resistance, Scott defines power as the luxury of "not having to act, or, more accurately, the capacity to be more negligent and casual about any single performance," and Bartsch's discussion of Tacitus's work about condititions under Nero utilizes this definition. ${ }^{10}$ Nero, while he is on stage, is actually the spectator, watching his subjects and how they reflect approval back at him; his own performance is the least interesting part of the exchange. The emperor, while acting, does not have to act, while the audience-and outside the theatre, all subjects-must act, must simulate accession to Nero's will. However, as Philo represents this relationship in the persons of Petronius and Gaius, both emperor and subject participate in deception, hiding their real motives and presenting a face advantageous for future relations. What remains constant, though, is that dissimulation follows weakness. On the one hand, Philo's presentation of Gaius and Petronius stays true to Scott's analysis of performance and power, hewing to the law that that acting is a part of being a subordinate; on the other hand, though, this scene in Philo's Embassy is novel because it represents power on both sides of the emperor-subject dyad. When Gaius perceives Petronius might have the power to do him harm, he hides his emotions as well as any subject.

The second scene to consider is a face-to-face interaction between Gaius and Agrippa, the Jewish king of Palestine (261-75). Unlike the first scene, here Gaius does not show any indications of hiding his motives from his subject. ${ }^{11}$ Still, this scene preserves a hint of the instability of the power

\footnotetext{
10) Bartsch, Actors in the Audience, 11, citing Scott, Domination, 29.

11) Josephus has a much different account of the interaction that takes place between Gaius and Agrippa. Agrippa, while still engaged in flattery, is able to address Gaius at an honorary banquet, and Gaius retracts his order to install a statue in the temple (Ant. 18.289-300).
} 
relationship between subject and emperor-a complexity that was not present in the portrayal of Nero by Tacitus. As Philo sets the stage for this scene, Agrippa is as yet unaware of the machinations of Gaius to install a statue in the temple. When the Jewish king arrives to pay his normal audience to Gaius, he knows "absolutely nothing" of the recent correspondence that had passed between Gaius and Petronius regarding the statue (261).

When Agrippa comes into Gaius's presence, however, it is clear that something is wrong, and Agrippa sets out to find out what it could be. As Philo reveals, Agrippa sees that Gaius is somehow disturbed and attempts to discover the root of his agitation:

He judged ... by his irregular movements and the disturbance shown in his eyes that anger was smouldering beneath, and he examined and searched himself in every way, setting his reason to work in every direction and on every possibility small or great, to see whether he had done or said something which he should not. (261)

We should not be surprised that Agrippa takes it upon himself to discern the reason for his emperor's mood: Sandra Citroni Marchetti has discussed the responsibility, newly incumbent on Romans as imperial subjects, of guessing the mind of the ruler. Writing about the negotiations with imperial rule undertaken by the friends of those in exile during the first century B.C.E. and the first century C.E., she notes that "a kind of interiorization of the will of Caesar develops at this time." One half of her study is devoted to the letters of Cicero written from exile, in which she finds that "the will of Caesar appears as a will that is scrutinized, interpreted, and imagined, rather than a will that is declared explicitly and necessarily followed." 12 The will of Caesar, for Cicero as an exile, and the will of Gaius, for Agrippa as a subject, both lie hidden beneath the surface. Agrippa's effort to discern the source of Gaius's fury, then, is not a situational invention, or something particular to Philo, but instead resonates with the techniques of other Roman writers active in the first centuries B.C.E. and C.E.

Much like in the scene with Petronius, Philo here acting as the author of the Embassy grants his readers access to Agrippa's thoughts, allowing him to display the dual nature of Agrippa's disposition. When it becomes

12) Marchetti, Amicizia e potere nelle lettere di Cicerone e nelle elegie ovidiane dall'esilio (Florence: Università degli Studi di Firenze, Dipartimento di scienze dell antichità "Giorgio Pasquali,” 2000), 73-74, my translation. 
clear to Agrippa that Gaius is not to be provoked, he adjusts his behavior to Gaius's mood:

[W] hen he saw him frowning and that his eyes had been fixed on no one else in the company but himself alone, he was frightened and though he was often minded to question him he forbore, reasoning thus: "Perhaps I shall draw upon myself the menace directed to others and have officiousness, rashness and effrontery imputed to me." (262)

Seeing that Gaius's angry glances seem to be directed only at him, Agrippa thus adjusts his usual disposition toward Gaius, attempting to avoid drawing the ire that is, to him, clearly stirring underneath Gaius's strange behavior. Even though he is accustomed to questioning Gaius, he instead keeps his questions to himself. Agrippa avoids asking even the most pressing question: Why is Gaius angry? This curtailing of Agrippa's inquisitive behavior matches one part of the complex of theatricality that Scott describes and that Bartsch locates in the period of Nero: the "attentive watchfulness and attuning of response to the mood and requirements of the powerholder" that is characteristic of a subject position. ${ }^{13}$

While in this formulation it is the subject who should be skilled at "reading" the moods and whims of the ruler, Philo as an author complicates his portrayal of Gaius by showing that he, too, attempts to read his subjects. Gaius scrutinizes Agrippa, and unfortunately for the Jewish king, proves much more astute than Agrippa:

Gaius, who was skilled in discerning a man's secret wishes and feelings from his open countenance, observed his agitation and perplexity and said, "You are perplexed, Agrippa, I will release you from your perplexity. Have you soujourned with me all this time and not learnt that I speak not only with my voice but quite as much with my eyes in every intimation that I make?" (263)

13) The quotation is drawn from Scott, Domination, 29, cited by Bartsch, Actors in the Audience, 11. She elaborates: "In its most general role of providing an interpretative paradigm for any exchange between two unequal interlocutors - the dominant one watching for the subordinate's correct performance, the subordinate watching to make sure his performance is giving rise to the desired effect - theatricality serves particularly well when the dominant member is felt to have a stake in controlling the appearance, and so the public meaning, of the interaction. That is, if as a subject I claim that I serve my emperor willingly, we both have a stake in maintaining the apparent truth value of that claim.” 
Gaius not only is able to see right through Agrippa's veneer of calm, he even goes so far as to taunt Agrippa, pointing out Agrippa's failure to read his motives while he demonstrates his own skill at discernment. We say that Gaius knows how to "read" Agrippa or that Agrippa has failed to "read" Gaius, but what is understood is that these men have more or less talent for examining the bodily responses of the adversary as an index to his inner state. In Agrippa's estimation of Gaius, it is by "his irregular movements and the disturbance shown in his eyes" (261) that Agrippa knows of Gaius's anger. Gaius, on the other hand, is able to simply "observe [Agrippa's] agitation and perplexity" (263); in this scene, Philo does not even stop to note Agrippa's demeanor, instead passing quickly to Gaius's observation, perhaps suggesting the facility Gaius has in judging emotions from the stance of the body.

This discernment of the body is actually a demonstration of power; we should see it as the foil to the skill necessary for negotiating the intricacies of the subject position, the ability to hide the bodily appearance of one's emotions, particularly fear. Scott suggests that "command performances" are incumbent upon subjects, and Bartsch agrees. What constitutes such a performance? As Scott describes it, "a convincing performance may require both the suppression or control of feelings that would spoil the performance and the simulation of emotions that are necessary to the performance... The performance... comprises not only speech acts but conformity in facial expression and gesture as well as practical obedience." ${ }^{14}$ It is this requirement to perform that is at the center of the idea of theatricality; indeed, as we saw in the exchange of letters between Petronius and Gaius, actions which defy imperial will are (almost) negligible, as long as they are accompanied by performances of subjection.

In his own interaction with Gaius, Agrippa is not able to perform in this manner: Agrippa's body, which has been so useful to Gaius as an indicator of Agrippa's inner fear, completely fails him at a crucial moment in the dialogue. When Gaius reveals the reason for his anger, it is far more global than Agrippa had imagined. Gaius informs Agrippa:

Your excellent and worthy fellow-citizens, who alone of every race of men do not acknowledge Gaius as a god, appear to be courting even death by their recalcitrance. When I ordered a statue of Zeus to be set up in the temple they

14) Scott, Domination, 28-29, cited by Bartsch, Actors in the Audience, 11. 
marshaled their whole population and issued forth from the city and country nominally to make a petition but actually to counteract my orders. (264-65)

Caught between his own desire to stay in Gaius's good graces and Gaius's anger regarding the Jews, Agrippa is unable to hide his terror at this news. Agrippa manifests in his body the complete shock of hearing Gaius's plans to place a statue in the temple:

Agrippa in deep distress turned to every kind of colour, blood-red, dead pale and livid all in a moment. And by now from the crown of his head to his feet he was mastered by a fit of shuddering, every part and every limb convulsed with a trembling and palpitation. With his nervous system relaxed and unbraced he was in a state of utter collapse, and finally thus paralyzed was on the point of falling. (266-67)

Because Agrippa is unable to come up with a response on the spot that might please Gaius - and save his own skin-his inner despair shows forth in an impressive display. ${ }^{15}$ As we have seen, the way for a subject such as Agrippa to maintain as much control as possible over his relationship to power is to keep a handle on his emotions. Thus, we should conclude, when Agrippa breaks down in front of Gaius, he essentially loses control.

Or does he? Perhaps Agrippa's fit is the one thing that could have possibly saved him from Gaius's wrath. Steven Weitzman has argued that the Jews' fame in antiquity as a group of people who would rather die than compromise the law actually functions as a survival strategy. The act of simulating death, thanatosis as Weitzman terms it, is a useful tactic for Jews

15) Interestingly enough, we have evidence of others who faint to escape imperial power. Bartsch cites two examples, one in Dio, one in Suetonius, of spectators who faint or fake death so as not to have to sit through Nero's performances (Dio, 63.15.2-3, and Suetonius, Nero 23.2, cited in Actors in the Audience, 5-6). For an example from a different context, see the charming description of the trembling book in Ovid's Tristia, written from exile after 8 C.E., where the book itself speaks, warning its reader that when it arrives in Augustus's presence, it might not be able to be read: "Wretched me! I fear the spot, I fear the man of power, my script wavers with shuddering dread. See you my paper pale with bloodless colour?" (III.1.53; cited in Marchetti, Amicizia, 277.) The letters themselves tremble, and the distinction between letters and page disappear with the loss of color-ironically, the book ceases to be legible because of this fit, while it is precisely at the moment of physical reaction that Agrippa becomes most legible to Gaius. 
to apply in their attempts to preserve tradition in the face of impending Roman sacrilege. ${ }^{16}$ Different from the Jewish literary tradition of "dying for the law," thanatosis is more a "suicidal feint," a rhetorical strategy that allows, for example, Josephus "as an author to exhibit the readiness of Jews to die for their tradition-and in this way align them with Roman values-without fully committing to death." ${ }^{\prime 17}$

This practice of thanatosis, he points out, is also present in the Embassy. ${ }^{18}$ When Petronius, the Syrian official familiar from the first of the two scenes discussed above, informs the Jewish elders in Jerusalem of what Gaius plans to do, they respond by letting him know the extent of their loyalty to the temple, saying:

We gladly put our throats at your disposal. Let them slaughter, butcher, carve our flesh without a blow struck or blood drawn by us and do all the deeds that conquerors commit. But what need of an army! our selves will conduct the sacrifices, priests of a noble order: wives will be brought to the altar by wifeslayers, brothers and sisters by fratricides, boys and girls in the innocence of their years by child-murderers. (233-34)

Rather than see the temple defiled, or even wait for Gaius's troops to kill them, the Jewish leaders offer to sacrifice themselves and do so in a way that suggests they are already in distress. ${ }^{19}$ This use of the suicidal feint by

16) Steven Weitzman, "Playing Dead" in Surviving Sacrilege: Cultural Persistence in Jewish Antiquity (Cambridge, MA: Harvard University Press), 138-57.

17) Weitzman, Surviving Sacrilege, 153; emphasis in original. Weitzman argues that Josephus is adapting the earlier tradition in a way that is less subversive than portrayals of outright suicide-understood in Roman culture as the ultimate expression of autonomy under tyranny. Thus Josephus's ambivalent understanding of suicide "reveals a Jewish imagination drawing on the Romans' own tradition of voluntary death (as inflected in the Flavian period) to fashion a new tactic of cultural survival, one that adapts the act of dying for the law, or rather the discourse that it inspired, so as to realign Jewish tradition and Roman rule" (145).

18) Weitzman, Surviving Sacrilege, 142.

19) Even though Philo is quick to present Jews as those who would gladly die for the continuation of the temple, in at least one place he gestures toward another motive for Jewish defense of Jewish "institutions." I essentially agree with Colson's translation of this difficult passage: "Now the Jews though naturally well-disposed for peace could not be expected to remain quiet whatever happened, not only because with all men the determination to fight for their institutions outweighs even the danger to life, but also because they are the only people under the sun who by losing their meeting-houses were losing also what they would have valued as worth dying many thousand deaths, namely, their means of showing reverence 
the Jewish elders is ultimately successful; it is what moves Petronius, "who was naturally kindly," and "was quite carried away both by what he heard and what he saw" (243), to stall Gaius's plans for the statue. The link between the portrayal of thanatosis by the Jewish crowd and Agrippa's rendition of death is even stronger if we consider, as Weitzman does, that the Jews' appeal is dramatically "intensified by gestures of desperation," such as Philo records, "made in great agitation and intense emotion accompanied with much gasping and spasmodic breathing, the sweat streaming over every limb amid a flood of ceaseless tears" (243). With this scene as a complement to Josephus's own depictions of approximated suicide, Weitzman argues that the strategy of thanatosis, or more colloquially, "playing dead," is a well-established trope in Second Temple literature.

In Agrippa's case, "playing dead" works as a delaying tactic. After his faint-or feint? - he is taken to his own house to rest and remains unconscious for a day and a half. When he comes to, he asks where he is; this is Philo's version of the response of those around him:

Cheer up, you are staying in your own house; Gaius is not here; you got a good rest when you fell asleep; now turn round, lift yourself up, lean upon your elbow and recognize the company present. They are all your own people, those of your friends and freedmen and servants who most value you and are valued by you. (271-72)

This speech indicates the security that Agrippa's fit has earned him. Not only has he remained out of the fray for a few days, with no responsibility to respond to Gaius's anger, he has gained a measure of safety by retreating to his own house, being surrounded by his own people. Agrippa makes good use of the time and space garnered by his act of thanatosis, composing a flattering yet frank letter of protest to Gaius from the remove of his own bed (276-329).

In both these cases, then, we see adumbrations of the kind of theatricality that Shadi Bartsch locates in Tacitus's writing about Nero, but we also see more. In the Embassy, we do not have to rely on third-person descriptions of theatricality between subjects and the emperor. Here, given access to the

to their benefactors, since they no longer had the sacred buildings where they could set forth their thankfulness" (Flaccus, 48). This passage, even if it is rhetorical flattery, would suggest that Philo could consider the Alexandrian synagogue more precious than life itself because it was a forum to give thanks for imperial euergetism! 
created world of interiority, we see underlings who attempt to manipulate imperial action, and in some ways, succeed. Petronius is able to delay the installation of the statue in the temple, and Agrippa buys himself enough time to compose a reasoned response to Gaius's anger. Even more noteworthy, however, is that we see dissimulation and deception where we do not expect it - in the person of the emperor. We could even say that we see theatricality where we do not expect it — not appearing for the first time in a unique form in the famous Roman historian's portrayal of Nero, but issuing from the pen of a Jew under Claudius.

\section{The Tools of Theatricality Put to Conservative Use}

Through this discussion of the Embassy, we have seen how Philo portrays theatricality between Gaius and his subjects, and we can identify this literary trope by several themes: the representation of an inner state which differs from the face one presents to the world, the importance of hiding one's inner state from one's adversary, the equally important skill of divining the inner state of another, and, in Philo's case, the direct access granted to a character's internal reasoning. In the cases we considered, subjectsand interestingly enough, the emperor-have two dispositions, or in James C. Scott's words, two "transcripts": one public, one hidden. For example, Petronius wishes to thwart Gaius's will to install a statue in the temple at Jerusalem, but he must present this attempt as motivated by a loyal caution on Gaius's behalf. Locating both transcripts in the thoughts or actions one character is a way for writers like Philo to depict the complex power negotiations involved in being subject to Roman rule.

If we widen the focus, so to speak, and look not only for this strategy of the theatrical paradigm - at its core, the awareness of more than one transcript in a single character-but for any use of the tools identified above, we will discover Philo's flexibility in representing the competing transcripts of power. In the Embassy, there are two different points of view regarding Gaius's character as emperor. One, presented in the voice of the narrator, Philo, considers Gaius's benificence and his later pretensions to divinity to have been a sham from the start. The other transcript resides with "the crowd," who succumbed to Gaius's seduction and believed every word. Using the same tools he did to represent the theatrical nature of relations between Gaius and Agrippa, or Gaius and Petronius, elsewhere in the Embassy, Philo simply locates these two transcripts in two different characters. By 
changing this element of the depiction of competing transcripts, dismantling the unity of the character who holds them both, Philo eliminates at one stroke the deception inherent in characters like Agrippa and Petronius. What ultimately results is a critique of Gaius's reign as emperor that manages to remain politically conservative, supporting the office of the emperor while condemning Gaius, and, perhaps more importantly, preserving the integrity of those persons who happened to survive: Philo, primarily, and the public.

The character who holds what might be otherwise called the hidden transcript - that transcript that records a scathing critique of Gaius-is Philo himself. Of course, the entire project of the Embassy is dedicated to exposing Gaius's true nature. Philo, of all those involved in the affairs described in the Embassy, is the only one who clearly sees Gaius's character. While Gaius was considered to be a godsend at first, he quickly changed, aspiring to become divine and murdering those whom he perceived as a threat. Philo sees this shift of aspect not so much as a change, but as a revelation of what had always been true of Gaius:

He who had been recently regarded as a saviour and benefactor, who would pour new streams of blessings on Asia and Europe, giving happiness indestructible to each singly and all in common, at once "ran amuck" as they say, changing to savagery, or rather revealing the brutality which he used to disguise under the mask of hypocrisy. (22)

The generous actions that Gaius took at the start of his reign were false from the beginning, simply a "mask" to cover over his "brutality." The Embassy also preserves a lengthy section of direct address in which the narrator, presumably here still Philo himself, ${ }^{20}$ upbraids Gaius for his grab at divinity. In it, the speaker declaims Gaius as a murderer, one who fears women, worthless as a benefactor, insatiable, "ignoble," coward, corrupter of cities, sower of destruction; one could not wish for a more complete, or

20) Elsewhere Philo warns of the danger of frank and open opposition to those in power: cf. Dreams, 2, 83-84, cited by Goodenough, Politics, 5. Given this kind of attitude against provoking authority, we may wonder whether the passage in question was inserted by a later editor of Philo's text. That doubt would certainly be sharpened by the awkward transition to and from direct address. In either case-if the passage were written after Gaius's death by Philo or if it were the addition of a later editor-what we have is a narrator who is aware of exactly the kind of treachery Gaius represents. 
more insulting, list of accusations (81, 86-92). The long tirade taunts Gaius, accusing him of falling short of the kinds of deeds expected from the gods that Gaius himself has attempted to emulate, even personify. In the terms of the narrative, Philo has observed Gaius closely enough to know his divine aspirations and is able to give voice to the havoc these aspirations have caused for the empire. In short, Philo has seen "under the mask," so to speak.

How is it, though, that Philo-or any other imperial observer-would come to know these aspirations? Important in the pair of scenes considered above, the observation of bodily disposition reappears here. At the end of Philo's tirade, as he finishes his comparison between the qualities of the gods and the laughable attempts of Gaius to imitate them, he tells us that

a divine form cannot be counterfeited as a coin can be... like an actor wearing in turn many kinds of masks he beguiled the spectators with the deceptive appearances he assumed. Well, one need not examine his characteristics of body and soul, since his every posture and movement showed the difference which divided him from the deity in question. (110-12)

Philo was able to unmask Gaius's deception, knowing that he was not divine, simply by watching Gaius's "every posture and movement."

In his role as both author of the Embassy and character in it, Philo's experiences with Gaius and his ability to discern Gaius's true nature are implictly in contrast with Agrippa's troubles with Gaius. The similarity continues when Philo also receives an initial audience with Gaius, one reminiscent of Agrippa's. Each attempts to guess at Gaius's intent, but they have different results. When Agrippa notices that Gaius is angry, he "[sets] his reason to work" in order to find out what might be the cause. When Philo arrives in Italy as the leader of the delegation, he also puts his reason to work, scrutinizing the actions of the emperor. When Philo and the other members of the envoy from Alexandria arrive from their journey, they are met by Gaius himself, who promises to hear their case in person (181). As Philo describes it, "as I believe myself in virtue of my age and my good education otherwise to possess a greater amount of good sense, what gave joy to the others rather alarmed me" (182). Philo alone of his group has his doubts about Gaius's intent, of which we learn-not surprisingly-in an extended representation of Philo's own thoughts:

Bestirring my thinking powers I said, "Why when so many envoys were present from almost the whole earth did he say that he would hear us only? What 
was his object? For he must have known that we were Jews who would be contented if they were not treated worse than others. To suppose that we shall take precedence with a despot of an alien race, a young man possessing absolute power, surely borders on madness; it looks as if he is attaching himself to the party of the other Alexandrians and it was to them that he gave precedence and promised to give judgment quickly, if indeed he has not discarded the idea of giving a fair and impartial hearing and instead of a judge become their advocate and our opponent." (182-83)

Philo here is the one person of the envoy who perceives the danger to himself and to the other Jews. Placed in the same situation as Agrippa, Philo is able successfully to perceive and to give voice to Gaius's underlying motives.

The implicit comparison between this passage and the interaction between Gaius and Agrippa continues in a striking manner. Just as Agrippa only understands the nature of Gaius's anger when he hears of the plans to install his likeness in the temple, so too the Jews with Philo only understand the danger they face once they hear of the imminent defilement of the temple. While Philo and his fellow diplomats were "anxiously considering the statement of [their] case," they are told of Gaius's plans to erect a statue of himself in the temple (186-89). Even though Philo could see the danger in their mission from the start, it is only with this confirmation of bad news that the rest of the envoy truly understands. When they hear, Philo describes, they manifest a reaction similar to Agrippa's:

As we marvelled at his words and, petrified by consternation, could not get any further, since we stood there speechless and powerless in a state of collapse with our hearts turned to water... Then gathered together in seclusion we bewailed the disaster personal to each and to all. (189)

Both the majority of the envoy and Agrippa had grossly underestimated the scope of Gaius's wrath, and the reaction of the envoy mirrors that of Agrippa: shock and paralysis, followed by withdrawal. Like Agrippa, it is in seclusion that they gather their thoughts and decide to press on to make a petition to Gaius.

Thus we see that Philo's presentation of the anti-Gaius transcript uses the tools of theatricality - the skill of divining another's motives, the manifestation of hidden emotions in the body-even to the point of implicitly mirroring one of the scenes of theatricality examined above, the exchange of letters between Gaius and Agrippa. To present the pro-Gaius 
transcript, on the other hand, Philo relies mainly on the technique of internal monologue; representing the thoughts of "the crowd," Philo shows us how the crowd is able to assent to, even excuse, Gaius's actions. For example, after the public hears of the several murders perpetrated by Gaius-who kills members of his family as well as of his court-Philo explains that there is an immediate reaction, "for a multitude is unstable in everything, intentions, words and deeds... They began to look for arguments of defense and by close search found them" (67). With clear evidence of Gaius's treachery before them, the multitude turns away from those facts and instead begins to mount an apologetic case for Gaius. We have access to these events through an extended representation of the crowd's thoughts, a technique which leads readers to draw several conclusions about the state of mind attributed to the crowd.

In the first section of this internal monologue, Philo allows us to see the faulty reasoning process of the crowd as it unfolds. Regarding the murder of Gaius's co-heir, Philo suggests that the crowd begins from a principle of what is natural and quickly goes astray:

Of his own cousin and fellow-heir they would talk thus: "Sovereignty cannot be shared, that is an immutable law of nature. He being the stronger promptly did to the weaker what the weaker would have done to him. This is defence, not murder. Perhaps, too, it was providential and for the benefit of all mankind, that the lad was put out of the way, since some would have been partisans of him and others of Gaius, and it is such things that create disturbances and wars both civil and foreign. And what is better than peace? But peace springs from right government. The only right government is that which is free from disputes and factions which also causes everything else to be carried on aright." (68)

Thus the public's reasoning, seemingly based on an "immutable" law, moves from one justification to another, finally alighting upon what seems to be the ultimate arbiter of good government: lack of dissent. While Philo gives no explicit commentary on this line of thought, his opinion is clear enough. The focus on "peace" by any means necessary in the crowd's thoughts simply places the violence necessary to produce that peace in greater relief, pointing up both how Gaius had to kill to arrive at an unchallenged empery, and, even more so, how the crowd had to twist its expectations, doing violence to reason, in order to maintain the unchallenged legitimacy of the emperor. 
As Philo begins the second section of the crowd's thoughts, that regarding the death of Gaius's long-time ally, Macro, ${ }^{21}$ we see him using internal monologue to ironic effect. He writes, "[o]f Macro they said: 'His pride extended beyond reasonable limits, he did not read well enough the Delphic motto "Know thyself." It is a common saying that knowledge is the source of happiness and ignorance of unhappiness" " (70). It is the crowd, clearly, who does "not know the truth. The human mind in its blindness does not perceive its real interest and all it can do is to take conjecture and guesswork for its guide instead of knowledge" (20-21). Taken in by both delusion and pride, avoiding knowledge, the crowd reasons poorly. Thus far, we have an account of the crowd and its support for Gaius that is relatively sympathetic. They may be fooled, but at least it is because of ignorance. Here in the discussion of Macro's murder, however, Philo complicates the crowd's innocence, if only slightly, when he writes: "in their thoughtlessness they [confused categories], whether they misunderstood the matter through stupidity, or in flattery recast the words and things signified by them away from their natural use" (70). In suggesting that flattery might be driving the crowd to excuse Gaius, Philo hints that the crowd might be complicit in Gaius's actions. ${ }^{22}$

Philo's presentation of the crowd's logic about another murder, that of M. Silanus, Gaius's father-in-law, demonstrates an even higher level of irony and subtle incrimination. Beyond simply presenting the faulty reasoning of the crowd, Philo shows the crowd projecting this faulty reasoning onto Silanus, the victim. They complain of him:

He was under a ridiculous delusion in thinking that a father-in-law had the same influence over a son-in-law as a real father has over his son, though, indeed, in private life fathers whose sons have obtained high offices and posts of authority waive their claims and are content to take the second place. But this silly man even though he had ceased to be a father-in-law extended his activities beyond his sphere and did not understand that the death of his daughter carried with it the death of a matrimonial affinity. (71)

The logical flexibility—even foolishness—of the crowd is striking. By this point, it should be clear to a reader of the Embassy that, in Philo's opinion,

\footnotetext{
21) Cf. Flaccus 12-15.

22) On the dangers to Roman subjects inherent in flattery, see Weitzman, "Friends in High Places," in Surviving Sacrilege, 55-78.
} 
it is the crowd itself which is "under a ridiculous delusion," reasoning in a "silly" manner.

Why would the public be so quick to make excuse for what in Philo's description is a blatant flouting of the rules of family, succession, and loyalty? While Gaius has "a deceptive and cunning nature" (59), the final blame does not rest on him. Instead, the public is led to legitimize Gaius's treachery because of the expectations they hold of the emperor. So pleased by the good fortune that comes with the start of his reign, they celebrate even more than is usual, expecting all manner of benefit to come now that Gaius holds the throne (10-11). Given this attitude at his accession, it was difficult for the crowd to square the benefactions that Gaius had undertaken with his ruthless behavior, and "what principally weighed with them was their wish to think that the emperor was not cruel" (73). As Philo tells us, " $\mathrm{t}]$ hey would not believe that Gaius, who but now had been thought kind and humane, showing fairness and fellowship to all, had undergone at once so complete a change" (67). Indeed, even as Philo makes it clear that this "change" was no change at all and simply a revelation of Gaius's nature, the multitude also wants to see continuity in the person of Gaius. Their grand welcome of him as emperor, Philo hints, has stunted their ability to assess his actions: "For as they had hoped that kindness and humanity were established in his soul in a greater degree than in any of his predecessors they thought it very incredible that he had undergone all at once so complete a change to the reverse" (73). The overall effect of internal access to the crowd's thoughts is to show us that their belief in Gaius, the pro-Gaius transcript, goes "all the way down," so to speak. There is no duplicity here, only dupes.

What is interesting, though, is that the hopes of the crowd and the criticism of Philo rest on the same foundation: an optimistic set of assumptions about the nature of authority and the person of the emperor. While Philo's extended scolding of Gaius was certainly harsh, it was, nevertheless, based on the standards provided by the deities, standards that an emperor should indeed strive after. Elsewhere in the Embassy, Philo's critique of the violation of the temple also is based on a certain standard: the reign of Augustus. He, the one "whom men fitly call the averter of evil," when presented at the beginning of his rule with an empire in disarray, proves to be the "Caesar who calmed the torrential storms on every side, who healed the pestilences common to Greeks and barbarians." He was the one who "not only loosed but broke the chains which had shackled and pressed so hard on the habitable world," "exterminated wars," "reclaimed every state 
to liberty," and "led disorder into order and brought gentle manners and harmony to all unsociable and brutish nations" (145-47). In an ironic twist, while Gaius managed for a time to hide his dark character under good deeds, for Philo, Augustus was the one who shared his good with all, who "kept nothing good and excellent hidden throughout his life" (147). If Augustus is the foil to which Gaius is compared and found lacking, then the two characters who represent competing transcripts regarding Gaius are also not so different at heart; both Philo and the crowd, as represented in the Embassy, desire a just emperor and the rightful exercise of authority.

The reason why Philo might choose to use the themes of theatricality, yet represent the competing transcripts in two different characters may lie in another quality that is shared by Philo and the crowd: both of them are yet participants in the empire of Claudius, the intended recipient of the Embassy. ${ }^{23}$ Any hint of deception or dissimulation on the part of either entity would jeopardize the position each holds in the current political landscape: Philo as Claudius's knowledgeable, trustworthy (and selfappointed) ambassador to the Alexandrian Jewish community, the crowd as those who praise and acclaim Claudius's actions. If - following Barbara Levick-one of the goals of the Embassy as a text is to manage Claudius's disposition toward the Jews, it would scarcely do to show either Philo or the crowd as participating in the double life so typical of others under Gaius as presented in the text. By splitting the competing transcripts into two different characters, Philo presents a safe version of both himself and the public. Here we see a treatise, and ultimately an author, who is critical of Gaius, but not of the office of the emperor.

Compared to other Roman imperial writers who use the technique of theatricality, then, Philo cuts a rather complex figure. His Embassy utilizes the techniques of theatricality in ways that are familiar and recognizably similar to Tacitus as he appears in Bartsch's study. The Embassy, however, goes one step further, rearranging the literary trope of theatricality in such a way as to deliver an account of the past that is critical of power, yet

23) At one point, Bartsch suggests that a similar situation may be affecting Tacitus's portrayal of Nero. She compares the text of Agricola, which seems to make Nero out to be unassuming compared to Domitian, to that of the Annals, which of course is dominated by Nero's machinations and his subjects' often unsuccessful attempts to produce the correct responses. The difference between the two texts, she argues, points out that Tactitus's use of theatricality as an interpretative paradigm may reflect more strategy than reality. See Actors in the Audience, 33-35. 
unchallenging to those who currently hold power. ${ }^{24}$ While this small treatise is one of our best sources of historical information for the position of Jews under Roman rule, it may also be considered as evidence that Philo, the Jew from Alexandria, is skilled in the apologetic and critical rhetoric of the Romans; indeed, as we have seen, he is in ways even more subtle than his Roman counterparts. The Philo examined here is perhaps a stranger to those whose academic interests reside with Judaism and likely a newcomer to those whose interests lie with classical studies. If this paper has presented a portrait of Philo that seems unfamiliar, it may be that this is simply a revelation of what had been hidden underneath the surface all along.

24) Cf. C. E. W. Steel, Cicero, Rhetoric, and Empire (Oxford: Oxford University Press, 2001), 4, where he argues that Cicero employs a similar tactic in order to develop a critique of Roman rule that does not challenge the fact of that rule, but only the individuals who inhabit the positions of power. It is clear, he says, that Cicero "is operating, in the speeches, with a concept of empire which depends not on territory, but on the power wielded by individuals, and that this in turn means that the problems which arise in the running of empire can be presented as the result of personal failings rather than endemic to the structures of government." 